\title{
What Schools Can Do to Prevent Teen Dating Abuse
}

\author{
Katherine van Wormer* \\ University of Northern Iowa, USA
}

Submission: February 22, 2017; Published: March 06, 2017

*Corresponding author: Katherine van Wormer, University of Northern Iowa, 247 Sabin Hall, Cedar Falls, IA Tel: 608-284-9746; Email: katherine.vanwormer@uni.edu

\section{Mini Review}

As we know from scientific research drawn from magnetic resonance imaging (MRI) revelations that the adolescent brain, and the region most closely associated with judgment, is not yet fully developed, not until around age 25 or 26 [1]. And with endorphins flooding their brains, young people (or middle aged people in mid-life crisis) are apt to enter into an intimate relationship, with their feet not quite on the ground. We know from a national US school survey that approximately $10 \%$ of high school students reported physical victimization and $10 \%$ reported sexual victimization from a dating partner in the 12 months before they were surveyed [2]. Most early dating situations have positive or at least neutral results and are good learning experiences because most people are fairly normal and careful not to harm the other person. But in some situations, the personality traits of one of the partners can lead to a lot of pain and misery for both of the individuals. "If only I had known what I was getting into; if only I had seen the signs." This is a statement made by many battered women who found themselves in a relationship that had gotten frightening and that they couldn't see any way of getting out of. Even when their friends warned them to break off, they already felt powerless to take action. But what if way back in school, they had learned the signs of what to watch out for, signs that could lead to serious problems and even violence later? What if they had learned about all-ornothing thinking patterns in themselves or others and about personality traits such as possessiveness and jealousy that can do so much harm? Love and hate can be closely intertwined in such a relationship. Schools need to teach about emotions such as jealousy so that girls when they are dating, instead of being flattered by bringing out jealousy in a boyfriend will recognize the insecurity that this emotion may represent. Schools need to teach about thought patterns that are unhealthy and about how extremist notions and behaviors can be controlled through selfawareness and training to catch the unhealthy self-talk. Many health education programs today are teaching about feelings and how the feelings can be controlled. This is part of harm reduction programming that also is a part of drug use (and binge drinking)

prevention. Such classes should also focus on dating violence prevention. The time to help teach adolescents about the hazards of dating violence coupled with the heavy drinking that is often associated with it is in middle school when dating first begins. To this end, the Centers for Disease Control and Prevention (CDC) [3] have begun developing a violence prevention campaign to help change social norms that support victimization. To first learn what the middle school dating norms are, they set up boys' and girls' focus groups. The common form of female-tomale violence discussed by the teens was slapping. Girls slapped boys as punishment when the boy was "out of line" or in selfdefense. Male participants described situations of retaliation or to assert themselves in front of their peers as reasons guys hit their girlfriends. The participants strongly disapproved of sexual violence. The consequences of involvement in an unhealthy relationship may range from psychological abuse to threats of suicide and even rarely to murder-suicide. Youth who experience dating violence are more likely to experience the following:

i. Symptoms of depression and anxiety

ii. Engagement in unhealthy behaviors, such as tobacco and drug use and alcohol

iii. Involvement in antisocial behaviors

iv. Thoughts about suicide [3]

In writing the book, Death by Domestic Violence, we filtered out from the literature on teen domestic violence warning signs that a relationship is abusive and that such violence is likely to escalate [4]. Here are the signs that could be discussed with young people in schools and religious group settings:

\section{Teen dating abuse: warning signs}

Based on the literature on domestic violence, we can note the following list of warning signs that a young woman should consider to determine if the relationship is likely to become violent. Many of these traits are relevant to young males entering close relationships as well, especially traits related to 
possessiveness and substance use. The warning signs are geared toward heterosexual female teens but can be adjusted to pertain to same-sex or male respondents and for different age groups.

i. Does your date or boyfriend brag about beating up or intimidating people?

ii. Does he ever suggest that he knows how to kill, for example, by playfully putting his hands on your neck, then say he was only joking?

iii. Does he own or have access to a gun or show a fascination with weapons?

iv. Has he ever forced you to kiss or have sex? Does he show a lack of awareness of your feelings?

v. Does he use illegal drugs, especially amphetamines, speed, meth, or crack?

vi. Does he get drunk on a regular basis or brag about his high tolerance for alcohol? Does he push you to drink alcoholic beverages or take illicit drugs?

vii. When you are with him, does he control how you spend your time? Is he always the one to drive or criticize you severely if you take the wheel?

viii. Is he constantly jealous? Does he control your friendships with other people and seem to want to have you all to himself?

ix. Is he rapidly becoming emotionally dependent on you; for instance, does he say things like "I can't live without you?" Is his thinking of an all-or-nothing pattern (either you are his best friend or his worst enemy-often about past relationships)?

x. Do you have the feeling that only you understand him, that others do not or cannot?

xi. Note the relationship between his parents. Is his mother very submissive to his father? Is there heavy drinking and/ or lots of tension in his family?

xii. Is there a history of past victimization by his father?

xiii. Is there a history of animal abuse in his background?

xiv. Has he ever struck you? Have you known him to lose control of his anger for certain periods of time?

xv. Has he ever threatened or tried to commit suicide?

xvi. Does he get out of patience quickly with children or is he verbally abusive toward them?

Total "Yes" answers.

If you have answered yes to two or more of these items, you should talk to a mature person before pursuing this relationship further. Before getting romantically involved with someone, consider what it would be like to break up with this person. Would you be able to cool the relationship and still remain friends or end the relationship if you wanted to? Consider how he would handle this. It is a lot easier to get out of a potentially dangerous relationship in the early stages than to wait and see how things turn out or to see whether or not you can change a person.

\section{References}

1. Arain M, Haque M, Johal L, Mathur P, Nel W, et al. (2013) Maturation of the adolescent brain. Neuropsychiatr Dis Treat 9: 449-461.

2. Vagi KJ, O'Malley Olsen E, Basile KC, Vivolo-Kantor AM (2015) Teen dating violence (physical and sexual) among US high school students: Findings from the 2013 National Youth Risk Behavior Survey. JAMA Pediatr 169(5): 474-482.

3. Centers for Disease Control and Prevention (CDC) (2016) Teen dating violence, USA.

4. Katherine Van Wormer, Albert R Roberts (2009) Death by domestic violence: Preventing the murders and the murder-suicides. Greenwood Publishing Group, USA, pp. 154-155.

\section{Your next submission with Juniper Publishers} will reach you the below assets

- Quality Editorial service

- Swift Peer Review

- Reprints availability

- E-prints Service

- Manuscript Podcast for convenient understanding

- Global attainment for your research

- Manuscript accessibility in different formats

( Pdf, E-pub, Full Text, Audio)

- Unceasing customer service

Track the below URL for one-step submission https://juniperpublishers.com/online-submission.php 